\title{
Partnership schemes in implementing mandatory garlic planting rules for importers: the case in East Lombok, Magelang, and Temanggung
}

\author{
Adhitya Marendra Kiloes ${ }^{1,2 *}$, Puspitasari ${ }^{2}$, Djoko Mulyono ${ }^{2}$, Sulusi Prabawati $^{2}$, Nirmala \\ Friyanti Devy ${ }^{3}$, and Hardiyanto ${ }^{3}$ \\ ${ }^{1}$ School of Agriculture and Food Science, The University of Queensland, 4343, Queensland, Australia \\ ${ }^{2}$ Indonesian Center for Horticulture Research and Development, 16111, Jawa Barat, Indonesia \\ ${ }^{2}$ Indonesian Citrus and Subtropical Fruits Research Institute, 65327, Jawa Timur, Indonesia
}

\begin{abstract}
National statistical data shows that almost all of Indonesia's garlic needs are imported from other countries. Local production is only less than $10 \%$ of the total national demand for garlic. The Indonesian government is currently working to increase national garlic production in order to reduce imports dependency. One of the efforts taken is to increase the planting area through mandatory planting regulations for garlic importers. Every importer is required to grow garlic in Indonesia, which, if converted, is equivalent to five per cent of the total imported garlic. Importers are given freedom regarding the planting mechanism, whether to plant by themselves or through the partnership scheme with farmers. Particularly for the partnership scheme with farmers, it is necessary to study a partnership scheme that is mutually beneficial for both parties. A study was conducted in 2018 as part of a horticultural development policy analysis research to examine the effectiveness of cooperation in implementing mandatory garlic planting regulations for importers. This research was conducted in three locations, East Lombok, Magelang, and Temanggung. This study found that each of the three locations has different cooperation schemes. Farmers are interested in forming partnerships with importers for several reasons: certainty of obtaining seeds and operational costs, and other reasons such as marketing certainty and the opportunity to get cultivation technology assistance.
\end{abstract}

\section{Introduction}

Garlic is a horticultural commodity that has many benefits. It is used as a cooking spice and is useful for treating various diseases due to its bioactive components useful for the biological process [1-3]. However, for Indonesia, garlic is a commodity whose supply still needs to be fulfilled by importing from other countries, mainly from China $[4,5,6]$. Indonesian garlic production only less than $10 \%$ of total national demand, and causes the national import trend

*Corresponding author: a.kiloes@uq.net.au 
to increase every year [5,7]. It is why garlic has always become the lowest production value of all strategic agricultural commodities in Indonesia [8]

In the past, Indonesia was able to produce its own garlic. This commodity is also a very profitable source of livelihood for many farmers in various regions in Indonesia. The peak of Indonesian garlic production occurred in the period 1990-1997 marked by the harvested area reaching 21 thousand hectares with garlic production reaching 150 thousand tons, and only less than $10 \%$ of imported garlic [9]. However, since the ratification of global trade regulations, Indonesia needs to open the import for imported garlic as wide as possible, which are cheaper. The existence of trade liberalization marked by the Asean-China Free Trade Area (ACFTA) agreement to reduce import duty on garlic from China has caused the price of imported garlic to be cheaper. The ACFTA agreement caused a surge in garlic imports in 2008 where the volume of imported garlic rose by 25 percent from the previous year [10]. With this garlic import, local Indonesian garlic has become less competitive, especially in terms of price. In addition, imported garlic also has a shape and specifications that are superior to local garlic, so that consumers prefer imported garlic to local garlic [11]. This condition has further worsened Indonesia's national garlic production and cause Indonesia to become the largest garlic importer in the world [10,12].

Through the Ministry of Agriculture, the Government of the Republic of Indonesia seeks to improve the competitiveness of local garlic. The goal is to achieve national garlic selfsufficiency $[5,13]$. Various kinds of special programs are carried out to achieve these goals, such as increasing the planted area and regulating garlic imports. Especially for the import of garlic, the Minister of Agriculture has issued regulation number 38 the year 2017 about Horticultural Product Import Recommendations, which regulates mandatory garlic planting for importers. This regulation is to adjust the condition where the market structure of garlic in Indonesia tends to be an oligopoly since only a few companies control most of the import of the product [6]. This regulation mentioned that importers must produce garlic by planting it in Indonesia, that if converted, the yield will be the same as $5 \%$ of the total of garlic they imported. Indirectly, the implementation of this rule will increase the area of garlic planted in Indonesia

The implementation of the mandatory garlic planting regulation for importers can be carried out in various ways. Garlic importing companies are given freedom in the mechanism of implementation. They can cultivate garlic independently or in partnership schemes with other parties such as farmers and farmers group in national garlic production centres. This partnership can benefit importers who do not have enough resources, especially land. In Indonesia, there is a limited amount of land suitable for garlic production. Garlic only grows optimally on highland between 600-1100 meters above sea level, with cold temperature and dry air [5]. However, partnerships must also bring benefits to partners, both farmers and farmer groups. The partnership mechanism with farmers involves the local government as the supervisor to implement these activities. The partnership mechanism that is carried out is also not regulated in detail in the existing regulations but must still pay attention to the principle of mutual benefit.

Some garlic importing companies have partnered with farmers and farmers groups in implementing this regulation. This partnership can be used as a model for the development of further partnership models. It is necessary to conduct a study to analyse each partnership model's development opportunities and weaknesses so that a partnership model that can benefit both parties can be recommended. Indirectly, this partnership model can support an increase in planted area to achieve national garlic self-sufficiency. 


\section{Methods}

This research is part of the horticultural development policy analysis carried out by a research team from the Indonesian Center for Horticulture Research and Development in 2018. Primary data was collected through semi-structured interviews with several farmers who have partnered with importers who were implementing mandatory garlic planting rules. Interviews were conducted in three garlic production centre districts in Indonesia, such as East Lombok in West Nusa Tenggara Province, and Magelang and Temanggung Districts in Central Java Province. Secondary data from the Directorate General of Horticulture and other related sources were used to complement this research.

A list of semi-structured interviews guideline was prepared to gather information, such as a set of questions to identify who was responsible for the input provisions, marketing scheme, and the role of importers in partnerships. The semi-structured interviews also identify the form of partnerships implemented and farmers' perceptions of partnerships, including weaknesses and expected partnership schemes by farmers. The semi-structured interview was conducted with 46 key-informant garlic farmers (20 in East Lombok, 11 in Magelang, and 15 in Temanggung) who participated in the partnership scheme with the importers to implement the mandatory garlic planting rules. It is a brainstorming process based on their understanding and experiences [14]. Descriptive content analysis was carried out to classify the answers to the results of the semi-structured interviews. Results and discussions.

\section{Results}

\subsection{Partnerships in East Lombok}

East Lombok is one of the garlic production centres in Indonesia. Garlic cultivation at this location is carried out at the foot of Mount Rinjani. Previous research revealed that more than 7000 hectares of land are suitable for garlic cultivation in this location. [13]. Garlic cultivation in this area is usually done in the dry season, combined with other crops [15]. The land used is paddy fields and dry land. The garlic variety that is commonly grown is Sangga Sembalun, a registered local superior variety [16].

In the location of garlic cultivation in East Lombok Regency, the form of a partnership carried out is by providing seeds by importers. The partnership is carried out on farmer's land with the smallest land area was 300 square meters to a maximum of 6000 square meters of farmers' land. When the research was conducted, a consortium of importers collaborated with farmer groups in the area. The consortium of importers provided imported garlic seeds, the Great Black Leaf variety from Taiwan. This variety has the same performance as the local variety Sangga Sembalun in terms of yield and shape. They also guarantee the marketing of farmers' crops, where a consortium of importers will buy back the crops of partner farmers at a price agreed in advance after the cost of providing seeds is deducted. In this partnership, farmers provide land, other inputs besides seeds and labour. As stated in the mandatory garlic planting regulations for importers, the local government, in this case, the local Department of Agriculture of East Lombok, is the supervisor of this partnership.

In this partnership, the productivity obtained by farmers varies from the smallest 3 tonnes/ha to the largest, reaching 20 tonnes/ha. On average, all interviewed key-important farmers produced a productivity of 9.29 tonnes/ha. This number is close to the average productivity of garlic carried out without a partnership scheme of around 12 tonnes/ha [4]. 


\subsection{Partnerships in Magelang and Temanggung}

Magelang and Temanggung Districts are two of the several centres for garlic production in Central Java Province. These two districts are located at the foot of Mount Sumbing. Garlic cultivation in this area is carried out on dry land during the rainy season. The varieties used include Lumbu Hijau and Lumbu Kuning, varieties that have been released nationally [4].

Unlike what was done in East Lombok, some companies partner with farmer groups individually, not as a consortium. Therefore, there are several partnership schemes implemented. In general, garlic importing companies provide production costs to farmers in a certain amount. It is the farmer's responsibility to provide inputs such as seeds, labour, and other input of production. Marketing was also the responsibility of farmers. They are free to sell their produced garlic to anyone at market prices. Some companies provide capital to farmers without requiring farmers to return the capital, and several other companies offer loans for garlic farming which will be partially returned according to the agreed proportion at the time of harvest. In these locations, farmer groups coordinated partnerships, with supervision from the Department of Agriculture in each district. From the partnership implemented, the productivity obtained by farmers ranges from 3-4.2 tonnes/ha, much smaller than normal productivity [4].

Table 1. Partnerships scheme of mandatory garlic planting regulation between importers and farmers.

\begin{tabular}{|l|c|c|c|}
\hline Variable & East Lombok & Magelang & Temanggung \\
\hline Seeds provision & $\begin{array}{c}\text { Seed provided by } \\
\text { importers, the cost of } \\
\text { providing seeds will } \\
\text { be deducted from the } \\
\text { farmer's harvest }\end{array}$ & $\begin{array}{c}\text { Seeds provided by } \\
\text { farmers }\end{array}$ & $\begin{array}{c}\text { Seeds provided by } \\
\text { farmers }\end{array}$ \\
\hline Inputs provision & $\begin{array}{c}\text { Inputs provided by } \\
\text { farmers }\end{array}$ & $\begin{array}{c}\text { Inputs provided by } \\
\text { farmers }\end{array}$ & $\begin{array}{c}\text { Inputs provided by } \\
\text { farmers }\end{array}$ \\
\hline Capital provision & $\begin{array}{c}\text { Varies, some } \\
\text { Capital provided by } \\
\text { farmers }\end{array}$ & $\begin{array}{c}\text { Varies, some } \\
\text { production costs that } \\
\text { some must be } \\
\text { returned when } \\
\text { harvesting, others } \\
\text { provide a sum of } \\
\text { money to farmers } \\
\text { without having to } \\
\text { return, with a smaller } \\
\text { amount }\end{array}$ & $\begin{array}{c}\text { production costs that } \\
\text { some must be } \\
\text { returned when } \\
\text { harvesting, others } \\
\text { provide a sum of } \\
\text { money to farmers } \\
\text { without having to } \\
\text { return, with a smaller } \\
\text { amount }\end{array}$ \\
\hline Marketing guarantee & $\begin{array}{c}\text { Guarantee marketing } \\
\text { at predetermined } \\
\text { prices }\end{array}$ & $\begin{array}{c}\text { Farmers are free to } \\
\text { sell to anyone at } \\
\text { market prices }\end{array}$ & $\begin{array}{c}\text { Farmers are free to } \\
\text { sell to anyone at } \\
\text { market prices }\end{array}$ \\
\hline Importers consortium & Exist & Did not exist & Did not exist \\
\hline
\end{tabular}

\subsection{Farmers' perception of current partnership scheme}

Garlic farmers in East Lombok are mostly satisfied with the partnership scheme proposed by a consortium of garlic importing companies. This satisfaction is because farmers feel they have certainty in getting agricultural input, especially seeds. At that time, farmers found it difficult to obtain local garlic variety seeds because of their small quantity and high price. Meanwhile, through the Ministry of Agriculture, the government of the Republic of Indonesia was actively implementing a garlic planting expansion program that required a lot of seeds. 
With the provision of imported garlic seeds of the Great Black Leaf variety from Taiwan, which have the same characteristics as Sangga Sembalun, farmers find it helpful to obtain seeds.

However, some farmers are still dissatisfied with the cooperation scheme proposed by the importer consortium. The dissatisfaction mainly was because even though the market is guaranteed, the prices given are still too low. Other dissatisfaction sources were because some farmers still have doubts about using the Great Black Leaf variety. Because of these doubts, they do not optimally take care of their crops, resulting in low productivity. A small proportion of farmers do not even take care of their crops, causing them to be unable to harvest the garlic they planted. Consequently, they have to bear the loss because they still have to return the cost of seeds to the garlic importer consortium. Some farmers are also still less satisfied with the communication established by the consortium of garlic importers. The farmers feel that they need to be assisted, especially in planting new varieties that they have never grown before.

However, the key farmers stated that they are still interested in participating in the partnerships that will be developed in the future. They are still interested, mainly if there is certainty in the price of output, assistance in access to inputs, and the availability of cultivation technology assistance. Some key farmers stated that the farmers in their group would be willing to provide more land if some of the things mentioned earlier could be agreed. For this reason, they feel the need for a renewal of the partnership scheme with a consortium of garlic importers.

Garlic farmers in Magelang and Temanggung are involved in a variety of partnership schemes. Therefore, their satisfaction with the partnership scheme will also depend on the form of partnership implemented. However, just like what happened in East Lombok, most of the farmers in the two regions in Central Java were satisfied with the cooperation scheme that was carried out. They feel helped by the availability of interest-free capital to plant garlic. Just like what happened in East Lombok, farmers feel the need for assistance in cultivation technology so that their garlic cultivation activities can run efficiently and more profitably. They also want marketing guarantees for growing garlic which they hope can be obtained from the partnership scheme carried out in the future.

\subsection{Proposed partnership scheme}

Based on case studies conducted in East Lombok, Magelang, and Temanggung, several recommendations for improving the efficiency of partnerships between farmers and importers in the context of implementing mandatory planting regulations for garlic importers can be delivered. This scheme will also be useful for implementing mandatory garlic planting rules for importers in other production centres. First, it would be better if garlic importers formed a consortium, as importers in East Lombok did. The existence of this consortium will uniform the partnership scheme carried out. Of course, the partnership scheme cannot be uniformed nationally, but at least it can be uniformed for each production centre, adjusted to the conditions of each production centre. This consortium will also make it easier for the local Department of Agriculture to supervise the implementation of the mandatory garlic planting rule. However, here the local government still needs to pay attention to the list of importers who are members of the consortium to ensure that each importer continues to carry out their responsibility. That is why the importer consortium needs to bridge the administrative process carried out at the local Department of Agriculture level. The consortium can be a specific body formed by importers or a company that provides consultation services regarding the partnership process.

Second, it is necessary to pay attention to the importance of marketing certainty for farmers. The decline in the national planting area of garlic since 1998 is the result of the local 
garlic price, which is not competitive with imported garlic. It would be better if the consortium of importers guarantees the marketing and price of garlic from the partnership scheme. With this guarantee, farmers will be more motivated to be involved in partnerships and indirectly will be more motivated to grow garlic. The partnership that has been carried out on chili can be taken as an example, which requires farmers to meet production quotas, but the harvested product will definitely be occupied at a predetermined price [17].

Third, it is necessary to improve communication between importers and farmers. The communication can be in the form of assistance from a consortium of importers related to efforts to improve the efficiency of garlic cultivation by applying more advanced technologies. The importer can carry this assistance if they have capabilities in technology assistance. Especially if they have more advanced technologies from other countries where the garlic they imported came from. The assistance can also be conducted through collaborationwith competent universities, research institutions, or some agricultural extension services providers. This scheme is also important because the mandatory regulation of garlic planting for importers requires that a minimum amount must be produced from the implementation of the regulation. Here, farmers have to achieve business efficiency, but importers also need to achieve the target of production.

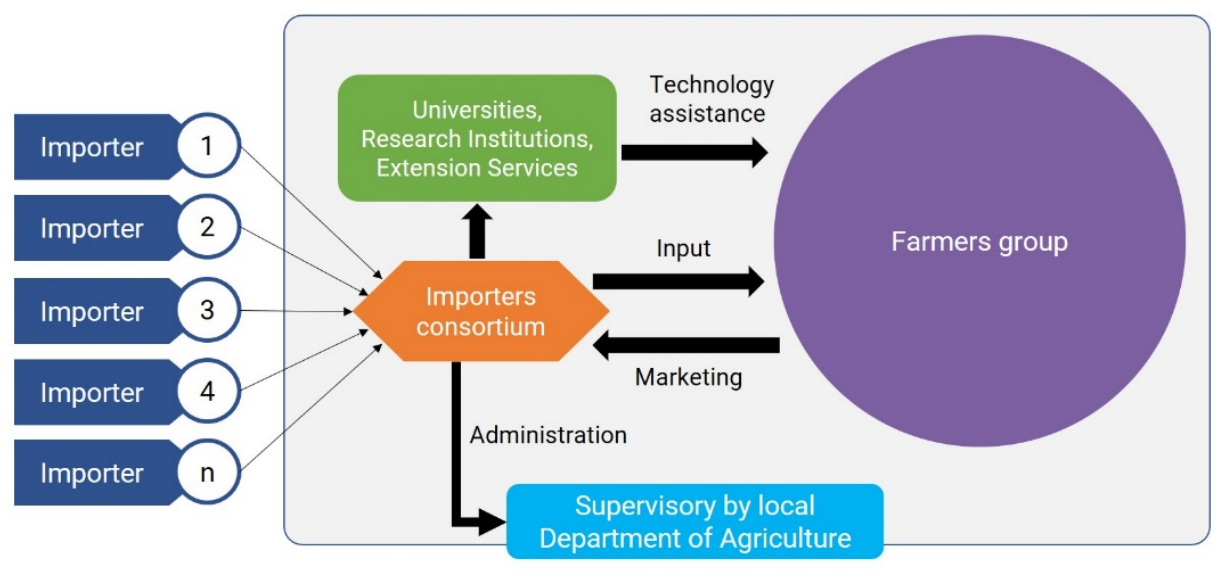

Fig. 1. Proposed partnership scheme for the implementation of mandatory garlic planting for importers.

\section{Conclusions}

This paper presents the results of research on the effectiveness of partnerships in implementing mandatory planting regulations for garlic importers. The results of the qualitative descriptive analysis show that, in general, there are two forms of partnership in three different garlic production centres. Some farmers are satisfied with the existing partnership and were interested in joining other partnerships in the future. However, the certainty of marketing the garlic they produce and assistance for the application of garlic cultivation technology needs to be part of the partnerships carried out in the future.Further research is needed in other production centres to further analyse the partnership scheme between importers and farmers to implement the mandatory regulation on garlic planting. This partnership can support increasing Indonesia's national garlic planting area in the context of national garlic self-sufficiency efforts. Certainty in marketing, especially for garlic 
that is not the result of a partnership, can increase the motivation of farmers to re-plant garlic and convert the land they are trying to grow garlic. So that it can help achieve the glory of Indonesia's national garlic again.

\section{References}

1. D. Prasonto, E. Riyanti, M. Gartika, ODONTO Dent. J. 4 (2017)

2. S. S. Prihandani, M. Poeloengan, S.M. Noor, Andriani, Inform. Pertan. 24 (2015)

3. A. Shang, S.Y. Cao, X.Y. Xu, R.Y. Gan, G.Y. Tang, H. Corke, V. Mavumengwana, Li H. Bin, Foods 8 (2019)

4. A.M. Kiloes, N. Hardiyanto, J. Hortik. 29 (2020)

5. B. Waryanto, T. Agustina, D. Tjiptodharmono, IOP Conf. Ser. Earth Environ. Sci. 335 (2019)

6. D. Amanda, Y. Syaukat, M. Firdaus, J. Int. Soc. Southeast Asian Agric. Sci. 22 (2016)

7. L. Hadiawati, M. Nazam, IOP Conf. Ser. Earth Environ. Sci., 637 (2021)

8. M.F.Z. Mardianto, S.M. Ulyah, E. Tjahjono, Int. J. Innov. Creat. Chang. 5 (2019)

9. Indonesian Ministry of Agriculture 2020 Commodity Outlook: Garlic Cent. Agric. Data Inf. Syst. (2020)

10. I.U. Yovirizka, T. Haryanto, Media Trend 15 (2020)

11. H.F. Noor, Kusnandar, Proc. NCMAB. (The Natl. Conf. Manag. Business), (2018)

12. B. Sayaka, Y.H. Saputra, D.K.S. Swastika, Anal. Kebijak. Pertan. 19 (2021)

13. R.Q. Muslim, A. Mulyani, IOP Conference Series: Earth and Environmental Science, 393 (Institute of Physics Publishing, 2019)

14. E. Pignatti, G. Carli, M. Canavari, J. Agric. Informatics, 6 (2015)

15. T. Sjah, D. Cameron, K. Woodford, J. Int. Agric. Ext. Educ., 13 (2006)

16. S.K. Mardiana, B.N. Utami, Hidayah, M.S. Mokhtar, Proceeding Int. Symp. Hortic. Kuta Bali, Indones. (Novemb. 27-30, 2018)

17. M.S.J. Anwarudin, A.L. Sayekti, A.K. Marendra, D.Y. Hilman, Pengemb. Inov. Pertanian., 6 (2015) 